\title{
PENGARUH KADAR TEPUNG KEPALA UDANG DAN WAKTU INKUBASI TERHADAP PRODUKSI BIOMASSA PROTEIN SEL TUNGGAL
}

\author{
Mohammad Saleh"), Marina**), Endang Sri Heruwati", dan Pipih Suptijah ${ }^{* * *)}$
}

\begin{abstract}
ABSTRAK
Percobaan pemanfaatan tepung kepala udang untuk pembuatan protein sel tunggal telah dilakukan untuk mendapatkan kadar substrat dan waktu inkubasi optimum bagi produksi maksimal biomassa sel. Tepung kepala udang dengan kadar 1\%, 4\%, 7\%, dan 10\% digunakan sebagai substrat dari jamur Trichoderma viride dengan inkubasi selama 4, 6, dan 8 hari pada $\mathrm{pH}$ 4,5 dan suhu $28^{\circ} \mathrm{C}$. Pengamatan dilakukan terhadap kadar protein dan kadar air protein sel tunggal, produksi (hasil biomassa kering), tingkat konversi (jumlah substrat awal dikurangi jumlah yang tersisa setelah panen), dan koefisien hasil biomassa (biomassa kering/g substrat terkonversi). Hasil percobaan menunjukkan bahwa kadar substrat berpengaruh terhadap produksi (yield), meskipun kadar substrat dan waktu inkubasi tidak berpengaruh terhadap kadar protein. Tingkat konversi tertinggi tercapai pada kadar substrat 1-4\% dengan waktu inkubasi 6 hari, tetapi koefisien hasil biomassa maksimum telah tercapai pada waktu inkubasi 4 hari dengan kadar substrat yang sama. Protein sel tunggal yang dihasilkan mempunyai kandungan protein $31,30 \%$; lemak 1,61\%; abu $15,66 \%$; dan serat kasar $28,20 \%$. Kadar senyawa nitrogen bukan protein, termasuk asam nukleat, cukup tinggi yaitu $3,12 \%$.
\end{abstract}

ABSTRACT: Effect of shrimp head meal concentration and incubation period on the biomass yield production of single cell protein. By: Mohammad Saleh, Marina, Endang Sri Heruwati, and Pipih Suptijah.

An experiment on the utilization of shrimp head meal to produce single cell protein was conducted to find out the optimum substrate concentration and incubation period for the maximum production of cell biomass. Shrimp head meal at concentrations of 1\%, 4\%, 7\%, and 10\% were used as substrate of Trichoderma viride with incubation periods of 4, 6, and 8 days at pH 4,5 and temperature of $28^{\circ} \mathrm{C}$. Observations were done for moisture and protein contents of the dried biomass, yield (weight of dry biomass), conversion rate (substraction of weight of substrate before and after incubation), and biomass yield coefficient ( $g$ dried biomass/g converted substrate). Results of the experiment revealed that substrate concentration affected the yield of SCP. However, protein content was not affected either by substrate concentration or incubation period.The highest conversion rate was achieved by substrate concentration of 1-4\% for 6-day incubation. However, the maximum biomass yield coefficient was achieved at 4-day incubation at the same concentration. The dry single cell protein produced contained $31.30 \%$ protein, $1.61 \%$ fat, $15.66 \%$ ash, and $28.20 \%$ crude fiber. Meanwhile, the non-protein nitrogen content (including nucleic acid) was considerably high $(3,12 \%)$.

KEYWORDS: Shrimp head meal, single cell protein, microbial growth.

\section{PENDAHULUAN}

Protein sel tunggal (PST) adalah suatu produk yang kaya akan protein, yang merupakan padatan biomassa dari sel bakteri, jamur, atau ragi (yeast) yang ditumbuhkan pada suatu substrat. Selain protein, produk ini juga mengandung karbohidrat, lemak, vitamin, mineral, dan serat kasar. Oleh karena itu, produk ini sering digunakan untuk pakan ternak, atau bahkan untuk

\footnotetext{
*) Peneliti pada Balai Penelitian Perikanan Laut

**) Mahasiswa Fakultas Perikanan IPB

***) Staf Pengajar IPB
} 
suplemen protein bagi manusia, setelah melalui proses pembersihan dan pemurnian (Mikalsen, 1983).

Pembuatan PST biasanya dikaitkan dengan pemanfaatan efektif dari limbah organik, seperti limbah pertanian (rumput, ampas buah anggur, penggilingan tebu, dll.), termasuk limbah peternakan dan perikanan (Litchfield, 1982). Proses yang sama juga digunakan untuk mengurangi BOD limbah berupa air buangan industri perikanan (Patel, 1988).

Dalam industri perikanan, limbah berupa kepala dan kulit udang sangat potensial untuk digunakan sebagai substrat dalam pembuatan PST mengingat jumlahnya yang cukup besar. Pada industri pengolahan udang kupas beku, jumlah limbah dapat mencapai $49 \%$ dari bobot udang (Balogun \& Samsons, 1992). Selain itu, kandungan khitinnya juga cukup tinggi, yakni sekitar 34,9-36,5\% dari bobot kepala dan kulit udang (Benjakul \& Sophanodora, 1993). Khitin merupakan polisakarida rantai panjang, dengan nama 2-asetil 2-amino deoksi D-glukosa dengan monomer-monomer yang berikatan satu sama lain melalui ikatan $1,4 \beta$.

Untuk memecah senyawa-senyawa yang umumnya berupa polisakarida ini diperlukan enzim pemecah polisakarida. Enzim ini dimiliki oleh banyak jenis mikroorganisme baik bakteri, jamur, maupun ragi. Beberapa di antaranya yang sering digunakan baik secara terpisah maupun secara bersama-sama untuk pembuatan PST adalah Azotobacter chroococcum, A.vinelandii, Brevibacterium flavum, Corynebacterium acetoacidophilum, Saccharomyces cerevisiae, Saccharomycopsis lipolitica, Candida utilis, Paecilomyces varioti, Aspergillus niger, A.oryzae, Geotrichum candidum, Trichoderma hanzianum, dan $T$. viride (Nudel el al., 1987; Vaccarino et al., 1992). Beberapa faktor seperti laju pertumbuhan spesifik, toleransi $\mathrm{pH}$ dan suhu, kebutuhan oksigen, stabilitas genetik, serta bebas dari sifat toksik dan patogen perlu dipertimbangkan dalam memilih jenis mikroorganisme yang akan digunakan.

T. viride sering digunakan dalam pembuatan PST terutama bila menggunakan substrat yang mengandung selulosa karena jamur tersebut memiliki enzim selulase lengkap yang mampu mengkatalisis konversi dari selulosa menjadi selobiosa dan dari selobiosa menjadi glukosa. $\mathrm{Di}$ samping itu $T$. viride juga menghasilkan khitinase yang dapat mendegradasi khitin. Pada medium sintetik jamur ini tumbuh pada kisaran suhu $20-28^{\circ} \mathrm{C}$ dan kisaran $\mathrm{pH} 3,0-7,0$, walaupun pH optimumnya antara 4,5-5,5. Jamur ini memerlukan sumber nitrogen, fosfor, mineral dan vitamin untuk pertumbuhannya. Mineral $\mathrm{Fe}^{++}$, $\mathrm{Mn}^{++}, \mathrm{Zn}^{++}$, dan $\mathrm{Co}^{++}$diperlukan untuk meng. induksi aktivitas enzim selulase (Mendels dan Reese, 1957). Pepton perlu ditambahkan ke dalam medium untuk menurunkan fase logaritmik dalam pertumbuhannya dan meningkatkan produksi enzim selulase maupun khitinase.

Mengingat produksi PST didasarkan atas pemecahan substrat oleh enzim yang dimiliki oleh mikroorganisme, maka kadar substrat akan merupakan faktor pembatas dalam efisiensi pemanfaatannya. Selain itu, karena proses konversi selulosa menjadi senyawa yang dapat digunakan oleh mikroorganisme memerlukan waktu, maka waktu inkubasi diperkirakan juga akan menentukan produksi PST. Untuk itu diperlukan penelitian guna mengetahui kadar substrat dan waktu inkubasi yang optimum dalam pembuatan PST menggunakan substrat tepung kepala udang.

\section{BAHAN DAN METODE}

Dalam pelaksanaan penelitian, pembuatan PST dilakukan di Laboratorium Instalasi Penelitian Perikanan Laut (Inlitkanlut) Slipi, sedangkan analisis kimia dilakukan di laboratorium Inlitkanlut Slipi serta laboratorium Pusat Antar Universitas Pangan dan Gizi dan AP4 (Agricultural Product Processing Pilot Plant), IPB. Kultur murni jamur $T$. viride yang digunakan diperoleh dari Laboratorium Mikrobiologi Pangan, Jurusan Teknologi Pangan dan Gizi, IPB, dengan media tumbuh dari Chalal (1985) yang dimodifikasi (Lampiran 1). Substrat berupa tepung kepala udang, dibuat dengan mengukus kepala udang selama 30 menit, kemudian mengeringkannya dalam oven $50^{\circ} \mathrm{C}$ selama 4 hari, diikuti dengan penggilingan dan pengayakan menggunakan saringan tepung.

Penelitian diawali dengan serangkaian percobaan pendahuluan. Percobaan pertama dimaksudkan untuk mengetahui perkiraan kadar substrat yang diperlukan. Untuk itu digunakan tepung kepala udang dengan kadar $10 \%, 20 \%$, $30 \%, 40 \%$, dan $50 \%$. Pada percobaan ini $\mathrm{pH}$ diatur 
pada $\mathrm{pH}$ yang dianggap optimum, yaitu $\mathrm{pH}$ 5,0 dengan inkubasi pada suhu kamar $\left(28^{\circ} \mathrm{C}\right)$ selama 6 hari. Dari percobaan ini ternyata pada semua kadar substrat yang dicoba, pertumbuhan jamur sangat lambat, sehingga pada percobaan utama, kadar substrat yang akan digunakan adalah antara $1-10 \%$. Percobaan berikutnya dilakukan untuk mencari $\mathrm{pH}$ dan suhu inkubasi yang optimum bagi pertumbuhan jamur. Untuk ini dicoba 3 perlakuan $\mathrm{pH}$ yaitu 4,$0 ; 4,5$; dan 5,0 ; dengan dan tanpa larutan penyangga sitrat $0,05 \mathrm{M}$, dan 3 perlakuan suhu inkubasi, yaitu $22^{\circ}$, $28^{\circ}$, dan $35^{\circ} \mathrm{C}$. Pada percobaan tersebut digunakan kadar substrat 4\% dan waktu inkubasi 6 hari. Semua percobaan pendahuluan menggunakan media tumbuh dari Chalal yang dimodifikasi. Hasil percobaan terakhir menunjukkan bahwa $\mathrm{pH} 4,5$ dengan larutan penyangga sitrat dan suhu inkubasi $28^{\circ} \mathrm{C}$ adalah yang terbaik untuk pertumbuhan jamur dalam percobaan ini.

Berdasarkan hasil percobaan pendahuluan di atas, maka penelitian dilakukan dengan memasukkan masing-masing $25 \mathrm{~mL}$ media tumbuh Chalal yang dimodifikasi dengan $\mathrm{pH} 4,5$ yang diberi larutan penyangga sitrat $0,05 \mathrm{M}$ ke dalam 24 labu erlenmeyer berukuran $125 \mathrm{~mL}$. Substrat tepung kepala udang dengan jumlah $1 \%, 4 \%, 7 \%$, dan $10 \%$ dari jumlah medium dimasukkan ke dalam setiap tabung, kemudian disterilkan pada suhu $121^{\circ} \mathrm{C}$ selama 30 menit. Setelah dingin, setiap tabung tersebut diinokulasi dengan $5 \mathrm{~mL}$ suspensi jamur yang berisi $1.5 \times 10^{7}$ spora, dan diinkubasikan pada suhu $28^{\circ} \mathrm{C}$ dengan waktu inkubasi 4, 6, dan 8 hari. Pemilihan waktu inkubasi ditentukan mengacu pada percobaan Putro (1982) dan Marwini (1986).

Setelah masa inkubasi selesai, miselia jamur dipanen dengan mengangkat lapisan miselia yang mengapung di permukaan medium. Miselia tersebut kemudian dikeringkan pada $40^{\circ} \mathrm{C}$ selama 24 jam (Putro, 1982) dan digiling menjadi tepung PST.

Pengamatan dilakukan terhadap produksi (yield), yaitu bobot biomassa kering yang dihasilkan dalam setiap labu percobaan. Dari data yang diperoleh dapat dihitung rendemen ( $\mathrm{g}$ biomassa kering per $100 \mathrm{~g}$ substrat) dengan memperhitungkan masing-masing bobot substrat tepung kepala udang dari setiap perlakuan. Terhadap PST kering yang diperoleh juga dilakukan pengamatan terhadap kadar air (dengan pengeringan oven pada $105^{\circ} \mathrm{C}$ ) dan kadar protein (dengan metode Kjeldahl).

Tingkat pemecahan substrat, yaitu persentase substrat yang digunakan oleh jamur untuk memproduksi PST, dihitung sebagai selisih antara bobot substrat awal dengan sisa substrat setelah selesai inkubasi dibagi dengan bobot substrat awal, dikalikan $100 \%$. Sisa substrat ditimbang setelah melakukan penyaringan terhadap media tumbuh yang sudah diambil miselianya, kemudian mengeringkan padatan yang tersaring. Untuk mengetahui efisiensi produksi PST, digunakan koefisien hasil biomassa dan koefisien hasil protein, yaitu jumlah biomassa kering dan jumlah protein yang dihasilkan oleh setiap gram substrat yang digunakan, yang dihitung dengan rumus berikut:

- koefisien hasil biomassa $=$

$$
\frac{\text { Produksi biomassa kering }(\mathrm{mg})}{\text { Bobot substrat awal - sisa substrat }(\mathrm{g})}
$$

- koefisien' hasil protein $=$

koefisien hasil biomassa $x$ kadar protein

Perlakuan yang memberikan hasil terbaik dipilih untuk memproduksi PST dalam skala yang lebih besar (5 liter), untuk kemudian diamati nilai gizinya. Untuk itu dilakukan analisis terhadap komposisi kimia yakni kadar air (dengan pengeringan oven pada $105^{\circ} \mathrm{C}$ ), abu (dengan oven pengabuan), protein (metode Kjeldahl), lemak (metode Soxhlet), serat kasar (dengan hidrolisis $\mathrm{HCl}$ ), dan senyawa nitrogen bukan protein (dengan ekstraksi TCA) dari PST yang dihasilkan.

Percobaan dilakukan dengan rancangan acak lengkap dengan sidik ragam menggunakan 3 ulangan.

\section{HASIL PENELITIAN DAN PEMBAHASAN}

\section{Produksi, Rendemen, dan Kadar Protein}

Jumlah PST yang diproduksi (yield) dari setiap perlakuan waktu inkubasi dipengaruhi oleh kadar substrat, walaupun bila dilihat dari rendemennya, tidak tampak adanya perbedaan antar perlakuan, kecuali pada kadar substrat 
$10 \%$ dengan waktu inkubasi 4 hari, dengan rendemen yang terkecil (Tabel 1). Tabel tersebut juga menunjukkan bahwa PST yang dihasilkan dari percobaan ini mempunyai kadar protein antara $32,44-63,00 \%$ (bobot kering), tanpa adanya pengaruh nyata dari kadar tepung kepala udang maupun waktu inkubasi. Tampaknya mutu PST yang dihasilkan, khususnya kadar protein, memang tidak berhubungan dengan banyaknya substrat yang diberikan maupun waktu inkubasi, tetapi lebih berkaitan dengan kemampuan spesies jamur dalam memanfaatkan substrat tepung kepala udang dan menyusunnya menjadi protein sel jamur itu sendiri. Pengaruh aktivitas enzim ekstra maupun intraseluler dan pengaruh lingkungan mikro tentu jauh lebih dominan di sini.

Dilihat dari tingginya kadar protein yang dicapai, jamur pada umumnya hanya dapat mencapai $15-45 \%$, tidak setinggi bakteri, yang dapat mencapai kadar protein 80\% (Hardjo et al., 1989).

\section{Efisiensi Produksi PST}

Efisiensi produksi, yang diukur menggunakan angka tingkat pemecahan substrat, koefisien hasil biomassa, dan koefisien hasil protein disajikan pada Tabel 2. Dari pengukuran tingkat pemecahan substrat diperoleh hasil bahwa perlakuan kadar tepung kepala udang 1-4\% dengan waktu inkubasi 6 hari memberikan tingkat pemecahan yang tertinggi dibandingkan dengan perlakuan lain. Pada perlakuan tersebut, jumlah substrat yang digunakan mencapai 38 $48 \%$. Di sini terlihat pengaruh nyata dari jumlah substrat maupun waktu inkubasi. Pada inkubasi 4 hari, pengaruh jumlah substrat terhadap tingkat pemecahan substrat memang belum terlihat. Tetapi dengan perpanjangan waktu inkubasi menjadi 6 hari, terlihat nyata bahwa kadar substrat di atas $4 \%$ memberikan tingkat pemecahan yang lebih kecil. Hal ini kemungkinan disebabkan oleh terhambatnya pertumbuhan jamur akibat diproduksinya senyawa amonia hasil pembusukan substrat yang berlebihan,

Tabel 1. Produksi, rendemen dan kadar protein dari protein sel tunggal.

Table1. Yield, production rate, and protein content of single cell protein.

\begin{tabular}{cccc}
\hline $\begin{array}{c}\text { Perlakuan } \\
\text { Treatment }\end{array}$ & $\begin{array}{c}\text { Produksi (yield) } \\
\text { (mg) }\end{array}$ & $\begin{array}{c}\text { Rendemen } \\
\text { Production rate } \\
(\%)\end{array}$ & $\begin{array}{c}\text { Kadar protein (Protein ct. }) \\
\text { (\%bobot kering/ \%dry weight) }\end{array}$ \\
\hline A1B1 & $11.15^{\mathrm{b}}$ & $4.46^{\mathrm{a}}$ & $47.69^{\mathrm{ac}}$ \\
A2B1 & $47.90^{\mathrm{ac}}$ & $4.79^{\mathrm{a}}$ & $32.44^{\mathrm{ab}}$ \\
A3B1 & $41.85^{\mathrm{ac}}$ & $2.39^{\mathrm{a}}$ & $42.35^{\mathrm{ab}}$ \\
A4B1 & $25.65^{\mathrm{bc}}$ & $1.03^{\mathrm{b}}$ & $49.64^{\mathrm{ac}}$ \\
A1B2 & $7.70^{\mathrm{b}}$ & $3.07^{\mathrm{a}}$ & $63.00^{\mathrm{c}}$ \\
A2B2 & $33.85^{\mathrm{bc}}$ & $3.39^{\mathrm{a}}$ & $53.94^{\mathrm{ac}}$ \\
A3B2 & $49.60^{\mathrm{bc}}$ & $2.84^{\mathrm{a}}$ & $33.21^{\mathrm{b}}$ \\
A4B2 & $69.10^{\mathrm{a}}$ & $2.77^{\mathrm{a}}$ & $56.98^{\mathrm{ac}}$ \\
A1B3 & $6.75^{\mathrm{b}}$ & $2.69^{\mathrm{a}}$ & $42.32^{\mathrm{ab}}$ \\
A2B3 & $19.75^{\mathrm{bc}}$ & $1.98^{\mathrm{ab}}$ & $44.39^{\mathrm{ac}}$ \\
A3B3 & $35.60^{\mathrm{bc}}$ & $2.04^{\mathrm{a}}$ & $58.97^{\mathrm{c}}$ \\
A4B3 & $56.60^{\mathrm{ac}}$ & $2.27^{\mathrm{a}}$ & $38.84^{\mathrm{ab}}$ \\
\hline
\end{tabular}

A: Kadar substrat (Substrate concentration): 1) 1\%, 2) 4\%, 3) $7 \%$, 4) $10 \%$

B: Waktu inkubasi (Incubation period): 1) 4 hari/days, 2) 6 hari/days, 3) 8 hari/days

Nilai dalam kolom diikuti huruf superskrip yang sama tidak berbeda nyata pada $\mathrm{P}=0,05$ (Values in collumn followed by similar superscript were insignificantly different at $P=0.05$ ) 
karena tepung kepala udang dalam percobaan ini dibuat tanpa terlebih dahulu membuang protein yang dikandungnya. Ferrer et al. (1996) dalam percobaannya memproduksi PST dengan membuang protein dari limbah udang melalui proses hidrolisis asam, dapat memperoleh kecepatan pertumbuhan mikroorganisme yang maksimum. Dengan waktu inkubasi yang lebih lama, tingkat pemecahan substrat dari keempat perlakuan tampak menurun, yang diduga tidak saja disebabkan oleh semakin banyaknya racun yang dihasilkan oleh proses pembusukan substrat, tetapi juga oleh semakin meningkatnya suhu dan semakin besarnya jumlah $\mathrm{CO}_{2}$ yang terdapat dalam setiap tabung percobaan sebagai akibat dari metabolisme jamur (Azzam et al., 1990). Sejalan dengan ini, Putro (1982) juga menemukan bahwa $T$. viride dengan kadar limbah udang
$1 \%$ pada $28^{\circ} \mathrm{C}$ dan $\mathrm{pH} 7,0$, mencapai pertumbuhan optimum pada hari ke-5, sementara Marwini (1986) dengan jenis jamur dan pada suhu yang sama tetapi menggunakan substrat laktosa $0,5 \%$, mendapatkan pertumbuhan optimum pada hari ke-4.

Dari perhitungan koefisien hasil biomassa terlihat bahwa efisiensi tertinggi dicapai pada awal masa inkubasi. Pada waktu inkubasi selama 4 hari, nyata terlihat perbedaan produksi biomassa kering per gram substrat antara kadar substrat $1 \%(349,40 \mathrm{mg})$ dengan $7 \%(161,69 \mathrm{mg})$, dan $10 \%(74,61 \mathrm{mg})$; serta antara $4 \%(284,32 \mathrm{mg})$ dengan $10 \%(74,61 \mathrm{mg})$. Adapun pada waktu inkubasi yang lebih lama, kemampuan produksi miselia kering per gram substrat terkonversi hanya berkisar antara $6,43-11,05 \mathrm{mg}$, tanpa ada-

Tabel 2. Tingkat pemecahan substrat, koefisien hasil biomassa, dan koefisien hasil protein PST.

Table2. Rate of substrate utilization, biomass yield coefficient, and protein yield coefficient of SCP.

\begin{tabular}{cccc}
\hline $\begin{array}{c}\text { Perlakuan } \\
\text { Treatment }\end{array}$ & $\begin{array}{c}\text { Tingkat } \\
\text { pemecahan } \\
\text { substrat } \\
\text { Rate of } \\
\text { substrate } \\
\text { utilization (\%) }\end{array}$ & $\begin{array}{c}\text { Koef. hasil biomassa (mg } \\
\text { biomasa/g substrat } \\
\text { digunakan) } \\
\text { Biomass yield coeff. } \\
\text { (mg } \begin{array}{c}\text { biomass/g utilized } \\
\text { substrate) }\end{array}\end{array}$ & $\begin{array}{c}\text { Koef. hasil protein (mg } \\
\text { protein/g substrat digunakan) } \\
\text { Protein yield coeff. (mg protein/g } \\
\text { utilized substrate) }\end{array}$ \\
\hline A1B1 & $13.00^{\mathrm{a}}$ & $349.40^{\mathrm{a}}$ & $162.39^{\mathrm{a}}$ \\
A2B1 & $16.77^{\mathrm{b}}$ & $284.32^{\mathrm{ab}}$ & $105.17^{\mathrm{ab}}$ \\
A3B1 & $14.89^{\mathrm{ab}}$ & $161.69^{\mathrm{bc}}$ & $67.92^{\mathrm{b}}$ \\
A4B1 & $15.45^{\mathrm{ab}}$ & $74.61^{\mathrm{c}}$ & $33.45^{\mathrm{b}}$ \\
A1B2 & $48.04^{\mathrm{c}}$ & $64.32^{\mathrm{c}}$ & $39.84^{\mathrm{b}}$ \\
A2B2 & $38.31^{\mathrm{c}}$ & $86.46^{\mathrm{c}}$ & $50.19^{\mathrm{b}}$ \\
A3B2 & $26.40^{\mathrm{d}}$ & $107.78^{\mathrm{c}}$ & $35.76^{\mathrm{b}}$ \\
A4B2 & $31.33^{\mathrm{e}}$ & $88.85^{\mathrm{c}}$ & $49.59^{\mathrm{b}}$ \\
A1B3 & $24.38^{\mathrm{df}}$ & $110.48^{\mathrm{c}}$ & $45.45^{\mathrm{b}}$ \\
A2B3 & $26.89^{\mathrm{d}}$ & $74.06^{\mathrm{c}}$ & $34.74^{\mathrm{b}}$ \\
A3B3 & $26.12^{\mathrm{d}}$ & $74.26^{\mathrm{c}}$ & $44.23^{\mathrm{b}}$ \\
A4B3 & $21.92^{\mathrm{f}}$ & $102.63^{\mathrm{c}}$ & $38.39^{\mathrm{b}}$ \\
\hline
\end{tabular}

A: Kadar substrat (Substrate conc.): 1: 1\%, 2: 4\%, 3: 7\%, 4:10\%

B: Waktu inkubasi (Incubation period): 1: 4 hari/days, 2: 6 hari/days, $3: 8$ hari/days

Nilai dalam kolom diikuti huruf superskrip yang sama tidak berbeda nyata pada $\mathrm{P}=0,05$ (Values in collumn followed by similar superscript were insignificantly different at $P=0.05$ ) 
nya perbedaan antar perlakuan. Hasil ini menunjukkan bahwa jamur mempunyai kemampuan memecah substrat yang tertinggi pada awal inkubasi (hingga 4 hari). Setelah itu ia tetap tumbuh dengan memanfaatkan substrat walaupun dengan kemampuan yang lebih rendah. Hal ini yang menyebabkan tingkat konversi maksimum tercapai pada hari ke-6 inkubasi. Pada inkubasi lebih lanjut, jamur telah mulai lambat pertumbuhannya, dengan kemampuan memecah substrat yang rendah pula, sehingga produksi PST maupun tingkat konversi substrat semakin rendah. Adapun perhitungan koefisien hasil protein menguatkan hasil berdasarkan bobot biomassa.

\section{Nilai gizi}

Berdasarkan hasil percobaan bahwa kemampuan produksi PST per gram substrat terkonversi tertinggi adalah pada kadar substrat $1-4 \%$ dan berdasarkan pertimbangan bahwa tingkat konversi tertinggi tercapai pada hari ke-6, maka diputuskan untuk memilih perlakuan kadar substrat 1\% dengan waktu inkubasi 6 hari sebagai perlakuan terbaik untuk memproduksi PST.

Hasil analisis kandungan gizi PST yang diproduksi dengan perlakuan tersebut disajikan pada Tabel 3 .

Kadar protein, serat kasar, dan abu yang tinggi serta kadar lemak yang rendah menunjukkan bahwa PST cukup baik bagi kesehatan bila dikonsumsi. Walaupun demikian, protein yang tinggi ini belum menjamin tersedianya nilai gizi yang tinggi pula mengingat PST mempunyai dinding sel yang keras sehingga pada umumnya nilai cerna proteinnya rendah. Azzam et al. (1990) menunjukkan bahwa PST yang diproduksi dari selulosa limbah pertanian menggunakan campuran antara T.viride dengan Candida utilis, mempunyai kadar protein kasar 35,5\% dengan nilai cerna dalam rumen in vitro hanya $69,8 \%$. Di sisi lain, bila dilihat dari kandungan senyawa nitrogen bukan protein yang cukup tinggi (3,12\%), PST dikhawatirkan mengandung asam nukleat yang tinggi pula. Kandungan asam nukleat yang tinggi pada makanan perlu dihindari karena dapat menyebabkan pembentukan batu ginjal atau penyakit tulang. Bila dikaitkan dengan ambang batas toleransi manusia terhadap asam nukleat sebesar 3 gram/hari (Said, 1987) dan diasumsikan bahwa sebagian dari senyawa nitrogen bukan protein adalah asam nukleat, maka konsumsi PST untuk manusia sebaiknya kurang dari 100 gram/hari. Selain itu, bau dan rasa PST yang agak langu juga merupakan kelemahan PST untuk tujuan konsumsi manusia, sehingga kemungkinan terbesar penggunaan PST dari hasil percobaan ini adalah untuk pakan ternak. Baik pada penggunaan untuk manusia maupun ternak, akan lebih aman bila sebelum dikonsumsi, jumlah asam nukleat pada PST direduksi terlebih dahulu, misalnya dengan menggunakan teknik pemanasan diikuti dengan pengepresan.

Tabel 3. Komposisi kimia PST kering yang dihasilkan dengan menumbuhkan T. viride pada tepung kepala udang $1 \%$ dengan inkubasi 6 hari pada $28^{\circ} \mathrm{C}$.

Table. 3. Chemical composition of dried SCP produced by growing $T$. viride at $1 \%$ shrimp head meal for 6 days at $28^{\circ} \mathrm{C}$.

\begin{tabular}{lc}
\hline \multicolumn{1}{c}{ Komposisi (Composition) } & $\begin{array}{c}\text { Persentase (Percentage) } \\
(\%)\end{array}$ \\
\hline Air (Moisture) & 14.41 \\
Abu (Ash) & 15.66 \\
Protein kasar (Crude protein) & 31.30 \\
Lemak (Fat) & 1.61 \\
Nitrogen bukan protein (Non-protein nitrogen) & 3.12 \\
Serat kasar (Crude fiber) & 28.20 \\
\hline
\end{tabular}




\section{KESIMPULAN DAN SARAN}

- PST dapat diproduksi menggunakan jamur T.viride dengan substrat tepung kepala udang dengan rendemen berkisar antara 1,03-4,79 gram (bobot kering) per 100 gram substrat.

Baik kadar substrat maupun waktu inkubasi tidak berpengaruh terhadap kadar protein PST, walaupun kadar substrat berpengaruh terhadap jumlah produksi (yield).

- Kemampuan optimal jamur dalam memproduksi PST per gram substrat tercapai pada kadar substrat $1-4 \%$ selama 4 hari inkubasi, tetapi tingkat konversi substrat tertinggi tercapai pada hari ke- 6 dengan kadar substrat yang sama.

Perlakuan kadar substrat $1 \%$, waktu inkubasi 6 hari pada suhu $28^{\circ} \mathrm{C}$ dan $\mathrm{pH} 4,5$ menghasilkan PST dengan nilai gizi yang cukup baik dalam hal kandungan protein dan serat kasarnya.

Mengingat kadar senyawa nitrogen bukan protein yang tinggi $(3,12 \%)$, yang kemungkinan berasal kadar asam nukleat yang tinggi kadarnya, penggunaan PST hasil percobaan ini untuk konsumsi manusia maupun ternak disarankan melalui proses pengurangan asam nukleat.

\section{DAFTAR PUSTAKA}

Azzam, A.M.; S. Ghoneim, and M.Z. Ebrahim. 1990. Pretreatment of agrocellulosic waste for microbial biomass production with a defined mixed culture. Food Biotechnol. 4(1):474.

Balogun, A.M., and A.Y. Samsons. 1992. Waste yield, proximate, and mineral composition of shrimp resources of Nigeria's coastal waters. Bioresource Technology 40(2):15'7-161.

Benjakul, S., and P. Sophanodora. 1993. Chitosan production from carapace and shell of black tiger shrimp (P. monodon). Asean Food J. 8(4):42-50.
Chalal, D.S. 1985. Solid state fermentation with Trichoderma reesei for cellulose production. Appl. Environ. Microbiol. Vol. 49:62-69.

Ferrer, J.; G. Paez; Z. Marmol; E. Ramones; H. Garcia, and C.F. Forster. 1996. Acid hydrolysis of shrimp shell waste and the production of single cell protein from the hydrolysate. Bioresource Technology. 57(1):55-60.

Hardjo, S.; N.S. Indrasti dan T. Bantacut. 1989. Biokonversi: Pemanfaatan limbah industri Pertanian. Dep. P \& K, Ditjen Perg. Tinggi, PAU Pangan dan Gizi, IPB, Bogor.

Litchfield, J.H. 1982. Meat, fish, and poultry processing waste. J. Water Pollut. Control-Fed. 54:688-692.

Marwini. 1986. Mempelajari produksi enzim selulase dari $A$. niger L51/NRRL, A-11, 264 dan T.viride. Skripsi Fak. Tekn. Pertanian IPB, Bogor.

Mendels, M., and E.T. Reese. 1957. Induction of cellulase in T.viride by carbon source and metal. J. Bacteriology 75:296.

Mikalsen, G.M. 1983. Single cell protein concentrate for use as feed additive. Patent. No. WO 8302388;21.07.83.

Nudel, B.C.; R.S.Wachner; E.R. Fraile, and A.M. Giulietti. 1987. The use of single and mixed cultures for aerobic treatment of cane sugar stillage and SCP production. Biol.Wastes 22(1):67-73.

Patel, T.R. 1988. Enzymes from fish waste with industrial application. Abstr.Pap. Am. Chem.Soc. 195 Meet.MBTD 70.

Putro, S. 1982. Studies on the suitability of chitinoclastic microorganism for shrimp waste fermentation. PhD Dissertation- University of Washington, USA .

Said, E.G. 1987. Bioindustri: Penerapan teknologi Fermentasi. P.T. Mediatama Sarana Perkasa. Jakarta.

Vaccarino,C; R.B. Lo-Curto; M.M.Tripodo; R.Patone, and A. Regmo. 1992. Grape marc as a source of feedstuff after chemical treatments and fermentation with fungi. Bioresource Technology. 40(1):35-41. 


\section{Lampiran (Appendix) 1.}

Media tumbuh untuk (growth media for) T. viride*)

\begin{tabular}{cc}
\hline $\begin{array}{c}\text { Nutrien/mineral } \\
\text { Nutrients/minerals }\end{array}$ & $\% \mathrm{~b} / \mathrm{v}(\% w / v)$ \\
\hline $\mathrm{KH}_{2} \mathrm{SO}_{4}$ & 14.0 \\
$\left(\mathrm{NH}_{4}\right)_{2} \mathrm{SO}_{4}$ & 9.8 \\
$\mathrm{Urea}$ & 2.1 \\
$\mathrm{MgSO}_{4} \cdot 7 \mathrm{H}_{2} \mathrm{O}$ & 2.1 \\
$\mathrm{CaCl}_{2} \cdot 2 \mathrm{H}_{2} \mathrm{O}$ & 2.1 \\
$\mathrm{FeSO}_{4} \cdot 7 \mathrm{H}_{2} \mathrm{O}$ & 0.035 \\
$\mathrm{MnSO}_{4} \cdot 4 \mathrm{H}_{2} \mathrm{O}$ & 0.01092 \\
$\mathrm{ZnSO}_{4} \cdot 7 \mathrm{H}_{2} \mathrm{O}$ & 0.0098 \\
$\mathrm{CoCl}_{2}$ & 0.0148 \\
$\mathrm{Bacto} \mathrm{pepton}$ & 3.5 \\
\hline
\end{tabular}

*) Modifikasi dari Chalal, 1985 (modified from Chalal, 1985) 